\title{
Resveratrol inhibits benzo[a]pyrene-DNA adduct formation in human bronchial epithelial cells
}

\author{
G Berge', S Øvrebø', IV Botnen', A Hewer², DH Phillips², A Haugen' and S Mollerup*,I \\ 'Department of Toxicology, National Institute of Occupational Health, PO Box 8 I 49 Dep, Oslo N-0033, Norway; ${ }^{2}$ Section of Molecular Carcinogenesis, \\ Institute of Cancer Research, Brookes Lawley Building, Cotswold Road, Surrey SM2 5NG, UK
}

Resveratrol (trans-3,4',5-trihydroxystilbene), a phytoalexin present in various plants and foods, has in several in vitro and in vivo studies demonstrated cancer chemopreventive and chemotherapeutic potential. We investigated the in vitro effect of resveratrol on benzo[ $[a]$ pyrene $(\mathrm{B}[a] \mathrm{P})$-induced DNA adducts in human bronchial epithelial cells. This was compared to the effect of resveratrol on the expression of the cytochrome P450 (CYP) genes CYPIAI and CYPIBI and the formation of B[a]P metabolites. Exposure of $\mathrm{BEAS}-2 \mathrm{~B}$ and $\mathrm{BEP} 2 \mathrm{D}$ cells to $\mathrm{B}[\mathrm{a}] \mathrm{P}$ and increasing concentrations of resveratrol resulted in a dose- and time-dependent inhibition of DNA adduct formation quantified by ${ }^{32} \mathrm{P}$-postlabelling. Supporting this result, resveratrol was shown to inhibit CYPIAI and CYPIBI gene expression, as measured by real-time reverse transcriptase-polymerase chain reaction. Also, a significant correlation was found between the number of DNA adducts and the mRNA levels of these genes. Using HPLC analysis, a concomitant decrease in the formation of $\mathrm{B}[\mathrm{a}] \mathrm{P}$-derived metabolic products was detected. In conclusion, these data lend support to a chemopreventive role of resveratrol in polycyclic aromatic hydrocarbon-induced carcinogenesis.

British Journal of Cancer (2004) 91, 333-338. doi: I0.1038/sj.bjc.6601898 www.bjcancer.com

Published online 25 May 2004

(C) 2004 Cancer Research UK

Keywords: DNA adducts; cytochrome P450; human bronchial epithelial cells; metabolites; PAH; real-time RT-PCR; resveratrol

Lung cancer is among the most frequent causes of cancer death in the western world today and the global incidence is increasing (Bilello et al, 2002; Kuper et al, 2002). Lung cancer is therefore expected to continue to have a major impact on human health throughout the next decades. The role of tobacco smoke as a major aetiologic factor in this malignancy is well established. Urban air pollution and occupational exposure may also increase the risk of lung cancer (Bilello et al, 2002). Approximately 25-30\% of adults in western populations are active smokers, and the number is increasing in developing countries (Peto et al, 1996). The fact that in the US and in some European countries, more than $40 \%$ of new lung cancer cases occur in former smokers, merits increased focus on studies to prevent the development of the disease (Tong et al, 1996).

Polycyclic aromatic hydrocarbons (PAH) are potent tobaccosmoke carcinogens and occur in complex mixtures in the environment (Hecht, 2003). Benzo[a]pyrene $(\mathrm{B}[a] \mathrm{P})$ is a major constituent of these mixtures and has been widely used as a model compound in studies of $\mathrm{PAH}$-induced carcinogenesis. $\mathrm{B}[a] \mathrm{P}$ is metabolically activated by enzymes in the cytochrome P450 (CYP) system to reactive electrophilic diolepoxides that are capable of binding to DNA (Denissenko et al, 1996; Hecht, 2003). CYP1A1 and CYP1B1, which are major PAH bioactivating enzymes, are induced by PAH in human lung tissue (Ding and Kaminsky, 2003). Thus, inhibition of PAH bioactivation and subsequent reduction of DNA adduct formation may be an important step in the prevention of smoking associated lung carcinogenesis.

*Correspondence: Dr S Mollerup; E-mail: steen.mollerup@stami.no Received 3 February 2004; revised 27 February 2004; accepted 5 April 2004; published online 25 May 2004
Although the confounding effect of alcohol drinking on lung cancer development is controversial and may be dose-dependent, epidemiological studies have indicated that wine consumers may have a lower risk of developing this cancer compared with consumers of other beverages (Prescott et al, 1999; De Stefani et al, 2002). Resveratrol (trans-3,4',5-trihydroxystilbene), a diphenolic phytoalexin, is present in high concentrations in red wines, as well as in berries and nuts (Fremont, 2000). In addition to a possible beneficial effect of resveratrol on the risk of coronary heart disease (Renaud and de Lorgeril, 1992; Hung et al, 2000), resveratrol has been suggested to have cancer chemopreventive potential by interfering with many cellular pathways. The compound has been shown to block tumorigenesis in a mouse model and to inhibit tumour growth and neovascularisation in rodents (Jang et al, 1997; Carbo et al, 1999; Kimura and Okuda, 2001). Besides the antiproliferative effects, induction of apoptosis has been demonstrated both in vitro and in vivo (Carbo et al, 1999; Mgbonyebi et al, 1998; Ahmad et al, 2001; Narayanan et al, 2003). Resveratrol has also been shown to modulate the expression of genes involved in the bioactivation of PAH (Ciolino and Yeh 1999; Mollerup et al, 2001).

In the present study, the effect of resveratrol on $\mathrm{B}[a] \mathrm{P}$-derived DNA adducts was investigated in the immortalised human bronchial epithelial cell lines BEAS-2B and BEP2D. Quantitative analysis of DNA adducts was compared to the effect of resveratrol on the expression of CYP1A1 and CYP1B1 and on the formation of $\mathrm{B}[a] \mathrm{P}$-derived metabolites. A time- and dose-dependent inhibition of $\mathrm{B}[a] \mathrm{P}$-induced DNA adduct formation by resveratrol was found. This correlated with the levels of CYP1A1 and CYP1B1 expression and concentration of $\mathrm{B}[a] \mathrm{P}$ metabolites. A long-term effect of resveratrol on $\mathrm{B}[a] \mathrm{P}$-metabolite formation was found. 


\section{MATERIAL AND METHODS}

\section{Chemicals}

Unless otherwise stated all chemicals were from Sigma (St Louis, MO, USA).

\section{Cell lines and culture conditions}

The immortalised human bronchial epithelial cell lines BEP2D and BEAS-2B were kindly provided by Drs JC Willey and CC Harris, respectively. The cells were maintained in LHC-9 medium (BioFluids, Rockville, MD, USA) containing $0.45 \mu \mathrm{g} \mathrm{ml}^{-1}$ bovine serum albumin, at $37^{\circ} \mathrm{C}$ in a humidified $5 \% \mathrm{CO}_{2}$ atmosphere. In the experiments, $80-90 \%$ confluent cell cultures were treated with $0-50 \mu \mathrm{M}$ resveratrol (Sigma, St Louis, MO, USA) in the presence of $1 \mu \mathrm{M} \mathrm{B}[a] \mathrm{P}$ (Sigma) for 24-120 h. After incubation, the cell culture medium was collected and kept at $-20^{\circ} \mathrm{C}$ until further analysis (high-performance liquid chromatography, HPLC). The plates were washed with cold phosphate-buffered saline, treated with trypsin (Sigma) and the cell pellet stored at $-70^{\circ} \mathrm{C}$ for RNA isolation and DNA adduct measurements. Solutions of resveratrol and $\mathrm{B}[a] \mathrm{P}$ were made in $100 \% \mathrm{DMSO}$. During the experiments, the final concentration of DMSO was $0.1 \%$. Experiments were performed in replicates of three and repeated several times, with similar results.

\section{Aromatic/hydrophobic DNA adducts}

DNA was extracted from cell pellets. Aromatic/hydrophobic DNA adducts were quantified by ${ }^{32} \mathrm{P}$-postlabelling analysis with the nuclease $\mathrm{P}_{1}$ modification as described previously (Phillips et al, 1990). Each sample was measured in parallel.

\section{Quantitative real-time reverse transcription-polymerase chain reaction (RT - PCR)}

Total RNA was extracted from cells by the TRIzol reagent (Invitrogen). mRNA was reverse transcribed by the aid of the 1st Strand cDNA Synthesis Kit for RT-PCR (AMV) using random primers (Roche Diagnostics, Basel, Switzerland). PCR primers (DNA Technology, Science Park Aarhus, Denmark) were designed to span introns to avoid amplification from traces of possible DNA contamination in the RNA isolation. Primers were checked for specificity by Blast search CYP1A1 forward, $5^{\prime}$-CAT CCC CCA CAG CAC AAC A-3'; CYP1A1 reverse, 5'-CAG GGG TGA GAA ACC GTT CA-3'; CYP1B1 forward, 5'-CTG GAT TTG GAG AAC GTA CCG-3'; CYP1B1 reverse, $5^{\prime}$-TGA TCC AAT TCT GCC TGC AC- $3^{\prime} ; \beta$-actin forward, 5'-GCG AGA AGA TGA CCC AGA TCA-3'; $\beta$-actin reverse, $5^{\prime}$-GAT AGC ACA GCC TGG ATA GCA A- $3^{\prime}$. These primer pairs give rise to PCR products of 152,143 , and $76 \mathrm{bp}$, respectively. During establishment of the real-time PCR method, PCR products were subjected to gel electrophoresis to ensure purity and correct fragment size. Quantitative analysis of the specific expression of various genes was performed by real-time PCR, on an ABI PRISM 5700 (Applied Biosystems, Foster City, CA, USA) with SYBRgreen I ( 40 cycles of $95^{\circ} \mathrm{C} 15 \mathrm{~s}, 60^{\circ} \mathrm{C} 1 \mathrm{~min}$ ). The amount of target cDNA in each sample was established by determining a fractional PCR threshold cycle number $\left(C_{\mathrm{t}}\right)$, and estimated by interpolation from a standard curve. The standard curve was made from known amounts of the corresponding product with the same primer sets, and was run on each PCR plate. The expression levels of CYP1A1 and CYP1B1 were normalised to the expression of the $\beta$-actin gene.

\section{High-performance liquid chromatography}

For the analysis of $\mathrm{B}[\mathrm{a}] \mathrm{P}$ metabolites, culture medium $(3 \mathrm{ml})$ from exposed cells was collected and stored at $-20^{\circ} \mathrm{C}$ until further processing. The medium was diluted to $10 \mathrm{ml}$ in $\mathrm{H}_{2} \mathrm{O}$, applied to a preconditioned (5 ml methanol and $10 \mathrm{ml}$ water) Sep-Pak $\mathrm{C}_{18}$ cartridge (Millipore Corporation, Milford, MA, USA), followed by a wash with $\mathrm{H}_{2} \mathrm{O}(10 \mathrm{ml})$, and eluted with $100 \%$ methanol $(5 \mathrm{ml})$. The methanol eluate was evaporated to dryness at $45^{\circ} \mathrm{C}$ under a nitrogen stream and resolubilised in $100 \mu \mathrm{l}$ of $100 \%$ methanol. HPLC separation of $\mathrm{B}[a] \mathrm{P}$ metabolites was performed on a NovaPak $\mathrm{C}_{18} 3.9 \times 150 \mathrm{~mm}^{2}$ column (Waters, Milford, MA, USA) with a Waters 625 LC System, equipped with a LC 240 fluorescence detector (Perkin-Elmer, Beaconsfield, UK). The $\mathrm{B}[a] \mathrm{P}$ metabolites were separated by a linear gradient of $30-100 \%$ methanol in $\mathrm{H}_{2} \mathrm{O}$ for $40 \mathrm{~min}$. For the quantitative determination of $\mathrm{B}[\mathrm{a}] \mathrm{P}$ tetrols, the following fluorescence conditions were used: $0 \mathrm{~min}$, ex 380/em 431; $0.5 \mathrm{~min}$, ex $341 / \mathrm{em} 381 ; 20 \mathrm{~min}$, ex $253 / \mathrm{em} 410 ; 27 \mathrm{~min}$, ex 380/em 431. The concentration of $\mathrm{B}[a] \mathrm{P}$ metabolite standards was determined by ultraviolet absorbance of the compounds dissolved in ethanol and using extinction coefficients from the NIH Chemical Carcinogen Repository (Midwest Research Institute, Kansas City, MO, USA).

\section{Statistical analysis}

The effect of resveratrol on the formation of DNA adducts, CYP expression and concentration of $\mathrm{B}[a] \mathrm{P}$-tetrol I-1 was investigated in four separate linear regression models. As cell line affected the level of response variables, it was included as a variable in all models. To achieve uniform variance throughout the data set, the response variables were log transformed in the analyses. Exposure time was considered a class variable. The concentration of resveratrol was treated as a continuous variable. The global model included resveratrol concentration, length of exposure, and the intercept between these two factors, and a backward stepwise method with $5 \%$ alpha level to exclude insignificant parameters. All analyses were carried out in R version 1.8.0 (Anon, 2003).

\section{RESULTS}

\section{Effect of resveratrol on DNA adducts}

The immortalised human epithelial cell lines BEAS-2B and BEP2D were incubated with a combination of $1 \mu \mathrm{M} \mathrm{B}[a] \mathrm{P}$ and increasing amounts of resveratrol for 24 or $72 \mathrm{~h}$. Treatment of both cell lines with $\mathrm{B}[a] \mathrm{P}$ in the absence of resveratrol resulted in a significant formation of DNA adducts, and the level was higher in BEP2D than in BEAS-2B (Figure 1). Cotreatment with $10-50 \mu \mathrm{M}$ resveratrol resulted in a dose-dependent inhibition in the number of DNA adducts $(\mathrm{F}=50.3, \mathrm{df}=1, P<0.0001$, for both lines combined). Incubation of BEAS-2B with $1 \mu \mathrm{M} \mathrm{B}[a] \mathrm{P}$ alone resulted in 26.1 and 80.9 adducts $10^{-8}$ nucleotides after 24 and $72 \mathrm{~h}$, respectively. At $10 \mu \mathrm{M}$ resveratrol, these levels were reduced by 67 and $62 \%$ (Figure $1 \mathrm{~A}$ and $1 \mathrm{~B})$. In BEP2D cells incubated with $1 \mu \mathrm{M} \mathrm{B}[a] \mathrm{P}$, a level of 95.5 adducts $10^{-8}$ nucleotides was measured after $24 \mathrm{~h}$, which increased to 652.1 after $72 \mathrm{~h}$ (Figure 1C and 1D). In the presence of $10 \mu \mathrm{m}$ resveratrol, a $51 \%$ decrease was found after $24 \mathrm{~h}$ (Figure 1C). At $10 \mu \mathrm{M}$ resveratrol, the high number of adducts formed after $72 \mathrm{~h}$ was reduced by $70 \%$ (Figure 1D). The inhibiting effect of resveratrol was more pronounced after 72 than $24 \mathrm{~h}(\mathrm{~F}=5.1$, $\mathrm{df}=1, P=0.047$, for both cell lines combined).

\section{Quantitative real-time RT-PCR}

The expression levels of CYP1A1 and CYP1B1 mRNA were determined in the human bronchial epithelial cell lines by realtime RT - PCR and normalised to the expression of $\beta$-actin. Data for BEAS-2B are shown in Figure 2. The BEP2D cells responded to $\mathrm{B}[a] \mathrm{P}$ and resveratrol exposure similarly as reported in Mollerup et al (2001). CYP1A1 mRNA increased from 24 to $72 \mathrm{~h}$ in both cell lines exposed to $\mathrm{B}[a] \mathrm{P}(\mathrm{F}=35.3, \mathrm{df}=1, P=0.0001)$. Cotreatment with increasing concentrations of resveratrol resulted in a 
A

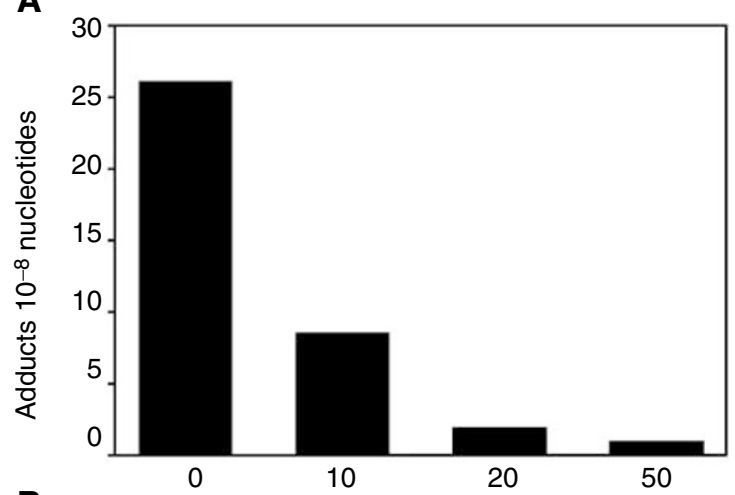

B

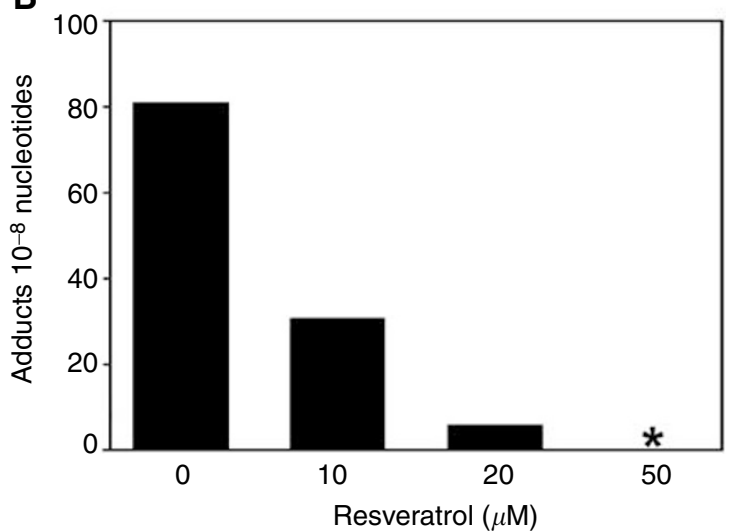

C

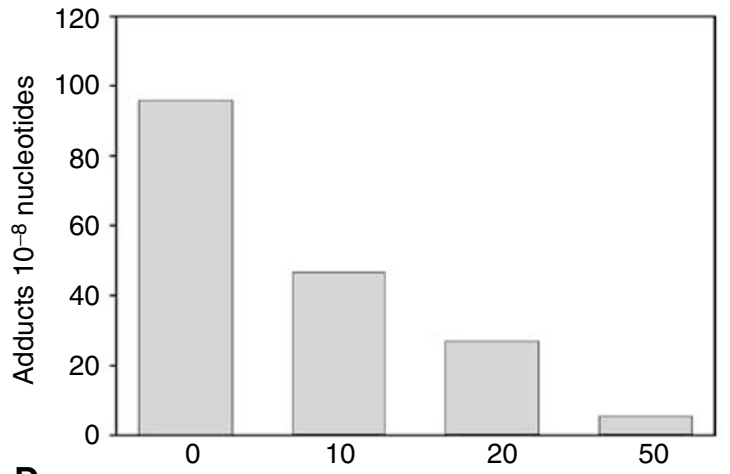

D

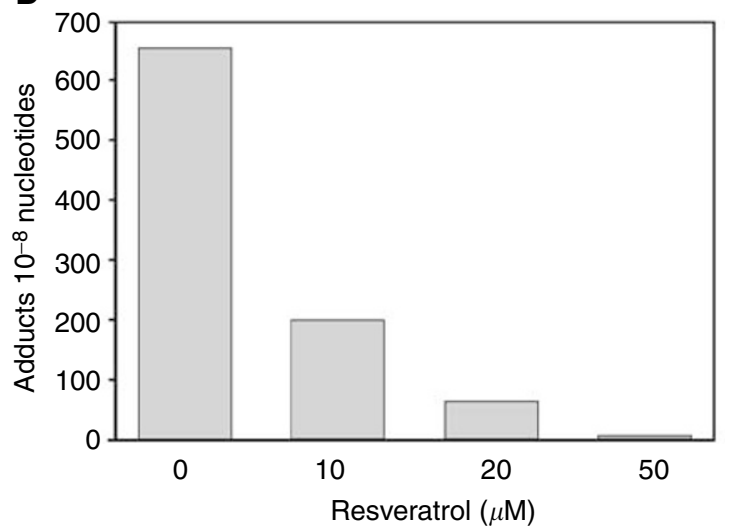

Figure I B $[a] P-D N A$ adducts measured by ${ }^{32}$ P-postlabelling in BEAS-2B (A and $\left.\mathbf{B}\right)$ and BEP2D cells $(\mathbf{C}$ and $\mathbf{D})$. The cells were treated with I $\mu \mathrm{M} B[a] \mathrm{P}$

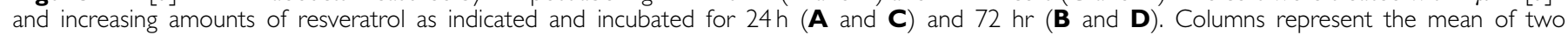
measurements from a representative assay. *Not performed.

decreased level of CYP1A1 mRNA $(\mathrm{F}=39.3, \mathrm{df}=1, P<0.0001$, for both cell lines combined). In BEAS-2B cells, $10 \mu \mathrm{M}$ resveratrol reduced CYP1A1 by 56 and $70 \%$ after 24 and 72 h, respectively. For $50 \mu \mathrm{M}$ resveratrol, the reduction was $97 \%$ at both time points (Figure 2A and 2B). In BEAS-2B cells, CYP1B1 mRNA appeared to be maximally induced by $\mathrm{B}[\mathrm{a}] \mathrm{P}$ after $24 \mathrm{~h}$ (data not shown). Increasing concentrations of resveratrol also inhibited CYP1B1 gene expression dose dependently at both time points (both cell lines combined: $\mathrm{F}=7.7, \mathrm{df}=1, P=0.0001$ ).

The expression levels of CYP1A1 and CYP1B1 were significantly related to the number of DNA adducts $(\mathrm{F}=19.7, \mathrm{df}=1, P=0.001$, and $\mathrm{F}=8.2, \mathrm{df}=1, P=0.01$, for CYP1A1 and CYP1B1, respectively). However, both genes are transcriptionally activated by the aryl hydrocarbon receptor (AHR), and the mRNA levels of the two genes were found to be strongly correlated.

\section{Effect of resveratrol on the formation of $\mathrm{B}[a] \mathrm{P}$ metabolites}

$\mathrm{B}[a] \mathrm{P}$ is metabolised into the carcinogenic diolepoxides, BPDE-I and BPDE-II. The effect of resveratrol on the formation of $\mathrm{B}[a] \mathrm{P}-$ tetrols was measured by fluorescence HPLC in the cell culture medium. The cells were treated with $1 \mu \mathrm{M} \mathrm{B}[a] \mathrm{P}$ and $0-50 \mu \mathrm{M}$ resveratrol for $24,48,72$ or $120 \mathrm{~h}$. The hydrolysis product of the ultimate carcinogen BPDE-I, B[a]P-tetrol I-1, was found as the most abundant form. In the absence of resveratrol, the formation of $\mathrm{B}[a] \mathrm{P}$-tetrol I-1 increased steadily during the 120 -h period (Figure 3). With the addition of resveratrol, the formation of the tetrol was inhibited in a dose-dependent manner throughout the incubation period in both cell lines $(\mathrm{F}=210.1, \mathrm{df}=1.58$, $P=0.0001)$. A time effect was found, where the effect of resveratrol increased with incubation time $(\mathrm{F}=4.4, \mathrm{df}=3.58, P=0.003)$. For BEAS-2B, incubation in the presence of $1 \mu \mathrm{M} \mathrm{B}[\mathrm{a}] \mathrm{P}$ led to an increase from $0.5 \mathrm{nM} \mathrm{B}[a] \mathrm{P}$-tetrol I-1 $(24 \mathrm{~h})$ to $18.5 \mathrm{nM} \mathrm{B}[a] \mathrm{P}$-tetrol I-1 $(120 \mathrm{~h})$. Cotreatment with $10 \mu \mathrm{M}$ resveratrol reduced the level by $60 \%$ after $24 \mathrm{~h}$ and $71 \%$ after $120 \mathrm{~h}$. At $50 \mu \mathrm{M}$ resveratrol, the concentration of the tetrol was below detection limits at all time points (Figure $3 \mathrm{~A}$ ). The BEP2D cells showed a similar pattern of induction and inhibition, while the concentration of $\mathrm{B}[a] \mathrm{P}$-tetrol I-1 reached higher levels than in the BEAS-2B. In BEP2D, a concentration of $57.0 \mathrm{nM}$ of the tetrol was measured after $120 \mathrm{~h}$ without resveratrol. At $50 \mu \mathrm{M}$ resveratrol, virtually no $\mathrm{B}[a] \mathrm{P}$-tetrol I-1 was detectable (Figure 3B).

The other tetrols $(\mathrm{B}[a] \mathrm{P}$-tetrol I-2, $\mathrm{B}[a] \mathrm{P}$-tetrol II-1, and $\mathrm{B}[a] \mathrm{P}-$ tetrol II-2) showed similar trends or were below detection limits.

\section{DISCUSSION}

The interest in chemicals effective in the reduction or inhibition of cancer is increasing and chemoprevention via nontoxic agents would greatly benefit public health. Plant-derived foods contain thousands of chemically dissimilar phytochemicals, many of which have been studied in vitro and in vivo to determine their effects on cancer risk and their mechanism of action. DNA adducts may be considered a risk factor for lung cancer, and their measurement can be used as a biomarker for PAH exposure (Phillips et al, 1988; Mollerup et al, 1999; Wiencke et al, 1999). In this study, we investigated the effect of resveratrol on premutagenic $\mathrm{B}[a] \mathrm{P}-\mathrm{DNA}$ adducts in the human bronchial epithelial cell lines BEAS-2B and BEP2D. We used ${ }^{32} \mathrm{P}$-postlabelling to quantify $\mathrm{B}[a] \mathrm{P}-\mathrm{DNA}$ adducts. Exposure to $1 \mu \mathrm{M}$ of $\mathrm{B}[a] \mathrm{P}$ led to a significant induction 

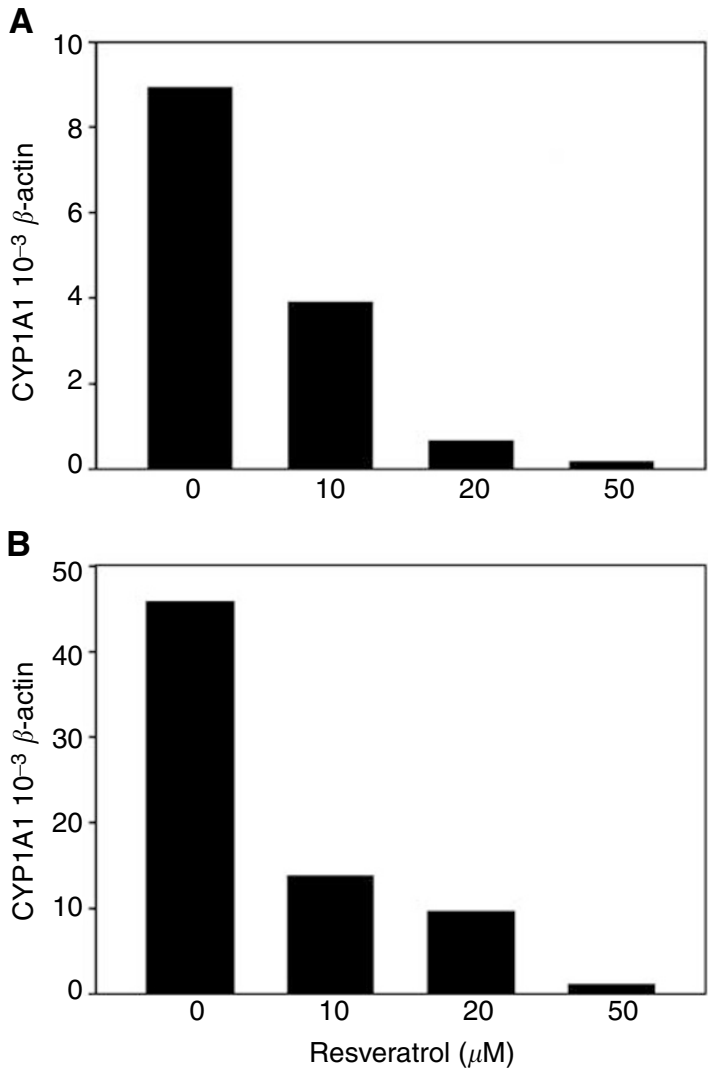

Figure 2 Real-time RT-PCR measurement of CYPIAI expression relative to the expression of $\beta$-actin in BEAS-2B cells. Cells were treated with I $\mu \mathrm{M} \mathrm{B}[a] \mathrm{P}$ and increasing amounts of resveratrol for $24 \mathrm{~h}(\mathbf{A})$ and $72 \mathrm{~h}$ (B). Columns represent the mean of repetitive PCRs from an experiment in which cells from two parallel Petri dishes were pooled during RNA isolation.

of adducts, which was inhibited by cotreatment with $10-50 \mu \mathrm{M}$ resveratrol in a time- and dose-dependent manner. The present report shows that resveratrol can inhibit the formation of a genotoxic end product of a tobacco-smoke carcinogen in human bronchial epithelial cells. The level of DNA adducts differed between the cell lines, being higher in BEP2D than in BEAS-2B. A concentration of $10 \mu \mathrm{M}$ resveratrol showed strong inhibitory effects on the level of DNA adducts and halved the number of adducts in both BEAS-2B and BEP2D after treatment for $24 \mathrm{~h}$. At $50 \mu \mathrm{m}$ resveratrol, an almost complete inhibition of DNA adduct formation in both cell lines for up to $72 \mathrm{~h}$ was observed. This indicates that resveratrol is a competent inhibitor of $\mathrm{B}[a] \mathrm{P}$ adduct formation irrespective of the bioactivating capacity of the cell line. In support of our data, Revel et al (2003) found by a semiquantitative immunohistochemical method that resveratrol inhibited lung $\mathrm{B}[a] \mathrm{P}-\mathrm{DNA}$ adduct formation in mice.

Resveratrol was found to exhibit a strong dose-dependent inhibition of both CYP1A1 and CYP1B1 expression. This is in accordance with previous data, where resveratrol inhibited the expression levels of CYP1A1 and CYP1B1 in BEP2D cells exposed to $\mathrm{B}[\mathrm{a}] \mathrm{P}$ for $24 \mathrm{~h}$ (Mollerup et al, 2001). In this study, we show that resveratrol had a long-lasting transcriptional inhibitory effect on both genes, which correlated with a reduced capacity to metabolise $\mathrm{B}[a] \mathrm{P}$. We have previously shown a significant relationship between CYP1A1 expression and the level of DNA adducts in normal human lung tissue (Mollerup et al, 1999). Similarly, in this in vitro assay the inhibition of CYP1A1 and CYP1B1 expression by resveratrol could significantly explain the reduction in the number
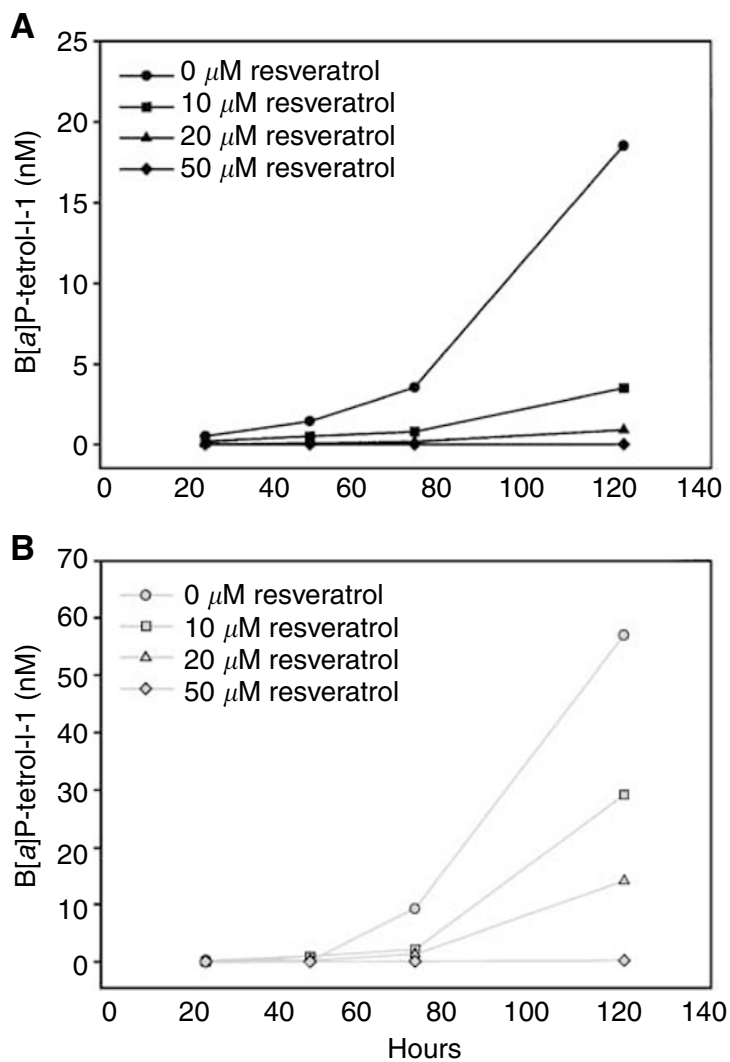

Figure 3 Effect of resveratrol on $\mathrm{B}[\mathrm{a}] \mathrm{P}$-tetrol $\mathrm{I}$ - I formation over time The cell lines BEAS-2B (A) and BEP2D (B) were treated with a combination of $1 \mu \mathrm{M} \mathrm{B}[a] \mathrm{P}$ and $0-50 \mu \mathrm{M}$ resveratrol as indicated. The cell culture medium was collected at 24, 48, 72 and 120 h of incubation. The levels of the $B[a]$-tetrol I- I metabolite in the medium were measured by fluorescence HPLC. Data points represent measurement of the medium from two parallel Petri dishes pooled at the end of incubation.

of DNA adducts. Decreased levels of CYP1A1 mRNA and protein activity and modulation of CYP1B1 expression by resveratrol has also been shown in other cell types (Ciolino and Yeh, 1999; Chang et al, 2000; Lee and Safe, 2001). Various molecular interactions have been proposed to be responsible for these inhibitory effects of resveratrol. Casper et al (1999) reported that resveratrol inhibited CYP1A1 expression by functioning as an aryl hydrocarbon receptor (AHR) antagonist. This is in contrast to studies by Ciolino and Yeh (1999) showing that resveratrol does not replace TCDD from AHR, but prevents the transformation of AHR to an activated nuclear DNA binding form. An AHR-independent posttranscriptional pathway has also been suggested, in which resveratrol increases the rate of CYP1A1 mRNA degradation (Lee and Safe, 2001). In addition, a direct inhibition of CYP1A1 enzymatic activity in cell free extracts has been shown (Chun et al, 1999; Ciolino and Yeh, 1999).

After exposure to $\mathrm{B}[a] \mathrm{P}$, the most abundant metabolite identified in the cell culture medium was $\mathrm{B}[a] \mathrm{P}$-tetrol $\mathrm{I}-1$, a hydrolysis product of the ultimate carcinogen BPDE-I. The formation of the tetrol was inhibited dose dependently by resveratrol from 24 to $120 \mathrm{~h}$. However, in the absence of resveratrol the rate $\mathrm{B}[a] \mathrm{P}$-tetrol $\mathrm{I}-1$ formation increased throughout the same incubation period. These results indicate a prolonged inhibitory effect of resveratrol on PAH metabolism and the inhibiting effect was found to be more pronounced over time.

The total beneficial effect of resveratrol may be a result of $\mathrm{e}$ ffects on various cell systems, and the compound may inhibit all of the initiation, promotion, and progression phases of carcinogen- 
esis. The ring structure of resveratrol makes it an antioxidant (Ray et al, 1999). In addition to CYP1A1 and CYP1B1, resveratrol may affect mRNA levels of genes involved in phase II drug-metabolising enzymes (Mollerup et al, 2001). Resveratrol has been shown to disturb cell cycle regulation and induce apoptosis. Both p53-dependent and -independent induction of apoptosis by resveratrol has been shown in various cell lines (Huang et al, 1999; Ahmad et al, 2001; Mahyar-Roemer et al, 2001; Narayanan et al, 2003). Apoptosis was also shown to be initiated in a tumour cell inoculation assay in rats (Carbo et al, 1999). Resveratrol also inhibited cell growth and modulated cell cycle in several human cancer cells (Mgbonyebi et al, 1998; Ferry-Dumazet et al, 2002). An antipromotion activity of the compound by inhibiting cyclooxygenase, as well as DNA polymerase and ribonucleotide reductase has been reported (Subbaramaiah et al, 1998; Fontecave et al, 1998; Sun et al, 1998).

\section{REFERENCES}

Ahmad N, Adhami VM, Afaq F, Feyes DK, Mukhtar H (2001) Resveratrol causes WAF-1/p21-mediated G(1)-phase arrest of cell cycle and induction of apoptosis in human epidermoid carcinoma A431 cells. Clin Cancer Res 7: 1466-1473

Bilello KS, Murin S, Matthay RA (2002) Epidemiology, etiology, and prevention of lung cancer. Clin Chest Med 23: 1-25

Carbo N, Costelli P, Baccino FM, Lopez-Soriano FJ, Argiles JM (1999) Resveratrol, a natural product present in wine, decreases tumour growth in a rat tumour model. Biochem Biophys Res Commun 254: 739-743

Casper RF, Quesne M, Rogers IM, Shirota T, Jolivet A, Milgrom E, Savouret JF (1999) Resveratrol has antagonist activity on the aryl hydrocarbon receptor: implications for prevention of dioxin toxicity. Mol Pharmacol 56: $784-790$

Chang TK, Lee WB, Ko HH (2000) Trans-resveratrol modulates the catalytic activity and mRNA expression of the procarcinogen-activating human cytochrome P450 1B1. Can.J Physiol Pharmacol 78: 874-881

Chun YJ, Kim MY, Guengerich FP (1999) Resveratrol is a selective human cytochrome P450 1A1 inhibitor. Biochem Biophys Res Commun 262: $20-24$

Ciolino HP, Yeh GC (1999) Inhibition of aryl hydrocarbon-induced cytochrome $P-4501 \mathrm{~A} 1$ enzyme activity and CYP1A1 expression by resveratrol. Mol Pharmacol 56: $760-767$

Denissenko MF, Pao A, Tang M, Pfeifer GP (1996) Preferential formation of benzo[a]pyrene adducts at lung cancer mutational hotspots in P53. Science 274: $430-432$

De Stefani E, Correa P, Deneo-Pellegrini H, Boffetta P, Gutierrez LP, Ronco A, Brennan P, Mendilaharsu M (2002) Alcohol intake and risk of adenocarcinoma of the lung. A case-control study in Uruguay. Lung Cancer 38: $9-14$

Ding X, Kaminsky LS (2003) Human extrahepatic cytochromes P450: function in xenobiotic metabolism and tissue-selective chemical toxicity in the respiratory and gastrointestinal tracts. Annu Rev Pharmacol Toxicol 43: 149-173

Ferry-Dumazet H, Garnier O, Mamani-Matsuda M, Vercauteren J, Belloc F, Billiard C, Dupouy M, Thiolat D, Kolb JP, Marit G, Reiffers J, Mossalayi MD (2002) Resveratrol inhibits the growth and induces the apoptosis of both normal and leukemic hematopoietic cells. Carcinogenesis 23: $1327-1333$

Fontecave M, Lepoivre M, Elleingand E, Gerez C, Guittet O (1998) Resveratrol, a remarkable inhibitor of ribonucleotide reductase. FEBS Lett 421: $277-279$

Fremont L (2000) Biological effects of resveratrol. Life Sci 66: 663-673

Hecht SS (2003) Tobacco carcinogens, their biomarkers and tobaccoinduced cancer. Nat Rev Cancer 3: 733-744

Huang C, Ma WY, Goranson A, Dong Z (1999) Resveratrol suppresses cell transformation and induces apoptosis through a p53-dependent pathway. Carcinogenesis 20: $237-242$

Hung LM, Chen JK, Huang SS, Lee RS, Su MJ (2000) Cardioprotective effect of resveratrol, a natural antioxidant derived from grapes. Cardiovasc Res 47: $549-555$
Modulation of PAH procarcinogen activation either by preventing the induction of metabolising enzymes or by inhibiting enzyme activity may be an important step in the chemoprevention of cancer and, in particular, lung cancer. This work shows that resveratrol can inhibit the formation of DNA adducts in human bronchial epithelial cells in vitro and supports a role for resveratrol as a chemopreventive dietary constituent. Further studies are needed to clarify whether this effect can be reproduced in an in vivo model of lung carcinogenesis.

\section{ACKNOWLEDGEMENTS}

We thank Ms Unn W Holm for excellent technical assistance and Ivar Herfindal for help with the statistical analyses. This study was supported by the Norwegian Cancer Society and Cancer Research UK.

Jang M, Cai L, Udeani GO, Slowing KV, Thomas CF, Beecher CW, Fong HH, Farnsworth NR, Kinghorn AD, Mehta RG, Moon RC, Pezzuto JM (1997) Cancer chemopreventive activity of resveratrol, a natural product derived from grapes. Science 275: $218-220$

Kimura Y, Okuda H (2001) Resveratrol isolated from Polygonum cuspidatum root prevents tumor growth and metastasis to lung and tumor-induced neovascularization in Lewis lung carcinoma-bearing mice. J Nutr 131: $1844-1849$

Kuper H, Adami HO, Boffetta P (2002) Tobacco use, cancer causation and public health impact. J Intern Med 251: $455-466$

Lee JE, Safe S (2001) Involvement of a post-transcriptional mechanism in the inhibition of CYP1A1 expression by resveratrol in breast cancer cells. Biochem Pharmacol 62: 1113-1124

Mahyar-Roemer M, Katsen A, Mestres P, Roemer K (2001) Resveratrol induces colon tumor cell apoptosis independently of p53 and preceded by epithelial differentiation, mitochondrial proliferation and membrane potential collapse. Int J Cancer 94: 615-622

Mgbonyebi OP, Russo J, Russo IH (1998) Antiproliferative effect of synthetic resveratrol on human breast epithelial cells. Int J Oncol 12: $865-869$

Mollerup S, Ovrebo S, Haugen A (2001) Lung carcinogenesis: resveratrol modulates the expression of genes involved in the metabolism of PAH in human bronchial epithelial cells. Int J Cancer 92: 18-25

Mollerup S, Ryberg D, Hewer A, Phillips DH, Haugen A (1999) Sex differences in lung CYP1A1 expression and DNA adduct levels among lung cancer patients. Cancer Res 59: 3317-3320

Narayanan BA, Narayanan NK, Re GG, Nixon DW (2003) Differential expression of genes induced by resveratrol in LNCaP cells: P53-mediated molecular targets. Int J Cancer 104: 204-212

Peto R, Lopez AD, Boreham J, Thun M, Heath Jr C, Doll R (1996) Mortality from smoking worldwide. $\mathrm{Br}$ Med Bull 52: 12-21

Phillips DH, Hewer A, Martin CN, Garner RC, King MM (1988) Correlation of DNA adduct levels in human lung with cigarette smoking. Nature 336: $790-792$

Phillips DH, Schoket B, Hewer A, Bailey E, Kostic S, Vincze I (1990) Influence of cigarette smoking on the levels of DNA adducts in human bronchial epithelium and white blood cells. Int J Cancer 46: $569-575$

Prescott E, Gronbaek M, Becker U, Sorensen TI (1999) Alcohol intake and the risk of lung cancer: influence of type of alcoholic beverage. Am J Epidemiol 149: $463-470$

Ray PS, Maulik G, Cordis GA, Bertelli AAE, Bertelli A, Das DK (1999) The red wine antioxidant resveratrol protects isolated rat hearts from ischemia reperfusion injury. Free Radic Biol Med 27: 160-169

Renaud S, de Lorgeril M (1992) Wine, alcohol, platelets, and the French paradox for coronary heart disease. Lancet 339: $1523-1526$

Revel A, Raanani H, Younglai E, Xu J, Rogers I, Han R, Savouret JF, Casper RF (2003) Resveratrol, a natural aryl hydrocarbon receptor antagonist, protects lung from DNA damage and apoptosis caused by benzo[ $a]$ pyrene. J Appl Toxicol 23: 255-261 
Subbaramaiah K, Chung WJ, Michaluart $\mathrm{P}$, Telang N, Tanabe T, Inoue $\mathrm{H}$, Jang M, Pezzuto JM, Dannenberg AJ (1998) Resveratrol inhibits cyclooxygenase-2 transcription and activity in phorbol ester-treated human mammary epithelial cells. J Biol Chem 273: 21875-21882

Sun NJ, Woo SH, Cassady JM, Snapka RM (1998) DNA polymerase and topoisomerase II inhibitors from Psoralea corylifolia. J Nat Prod 61: 362 - 366

Tong L, Spitz MR, Fueger JJ, Amos CA (1996) Lung carcinoma in former smokers. Cancer 78: $1004-1010$

Wiencke JK, Thurston SW, Kelsey KT, Varkonyi A, Wain JC, Mark EJ, Christiani DC (1999) Early age at smoking initiation and tobacco carcinogen DNA damage in the lung. J Natl Cancer Inst 91: $614-619$ 